\title{
ILMU SEBAGAI PROSEDUR (METODE MEMPEROLEH PENGETAHUAN ILMIAH)
}

\author{
Lailatul Maskhuroh $^{1}$
}

\begin{abstract}
Knowledge always develops from the beginning until now. It is appears immediately along with the process of human thinking. At first knowledge is gained by the way of informal process of thinking, not related with existing methods. Then various changes have been done by figures that appear after doing organized towards knowledge that found by them. In the next development, human being makes knowledge as the result of thinking which is definitely scientific and is appropriate with procedure of human thinking that mentioned in the rules of the syllogism think. From several methods of obtaining knowledge, among of them are rasionaslime method, empiric, phenomenalism, intusionalism, and scientific method, while elements in the scientific method as scientific research among other through several procedures, such as formulation of problem, proposing a hypothesis, testing a hypothesis with empirical fact, and making a decision.
\end{abstract}

Keywords : Science, Procedure, Knowledge, and Scientific Method.

\section{A. PENDAHULUAN}

Pembahasan tentang ilmu pengetahuan (science) merupakan pembahasan yang akan selalu menarik dan akurat, karena ilmu pengetahuan merupakan sesuatu yang berkembang secara alamiah sesuai dengan perkembangan pemikiran manusia yang sangat peka terhadap proses interaksi yang dilakukan oleh manusia dengan lingkungan sekitarnya. Ia merupakan hasil tautan antara manusia dengan fenomena lingkungan sekitarnya. Tim dosen Filsafat Ilmu Fakultas Filsafat UGM, (2003: 64 )

Pada zaman dahulu bisa kita lihat dari penemuan-penemuan ilmu pengetahuan yang ditemukan oleh tokoh-tokoh filosof terdahulu pada zaman Yunani kuno. Pada masa itu, proses pemenuhan kebutuhan hidup manusia masih menggunakan alat-alat yang terdiri dari batu. Sehingga aktivitas ilmiah manusia masih sangat sederhana.Tetapi pada perkembangan selanjutnya,.mereka bukan saja menyumbang

1 Dosen STIT al-Urwatul Wutsqo Diwek Jombang, email : lela.jombang@gmail.com, 
perkembangan ilmu dengan astronomi, kedokteran, dan sistem klasifikasi Aristoteles, namun juga silogisme yang menjadi dasar bagi penjabaran secara deduktif pengalaman-pengalaman manusia. Terlepas dari tendensi mereka untuk menitikberatkan teori - dengan sering melupakan pengalaman empiris - dan kurang memperhatikan percobaan sebagai sumber bukti-bukti keilmuan, bangsa Yunani dapat dianggap sebagai perintis dalam mendekati perkembangan ilmu secara sistematis. George J. Mouly, (1999: 87) Maka hasil dari proses perenungan yang mereka lakukan sedikit demi sedikit menjadi lebih formal. Hal ini menjadikan ilmu pengetahuan menjadi hasil berifikir yang betul-betul ilmiah sesuai dengan prosedur berpikir manusia yang tertera dalam kaidah-kaidah berfikir silogisme.

Di dalam proses pencarian ilmu pengetahuan yang dilakukan setiap manusia yang hidup tidak lepas dari tujuan-tujuan yang khusus, itu tergantung kepada lingkungan sekitarnya yang menuntut untuk bertindak ilmiah. Ilmu sebagai suatu proses rasional manusia yang melibatkan nalar dan perasaan manusia menuntut adanya teoriteori sistematis yang akan membimbing mereka untuk menemukan keputusan-keputusan ilmiah yang dapat dipertanggung- jawaban, sehingga setiap ilmuan dituntut untuk merumuskan tujuan-tujuan tersebut sebagai prosedur khusus dalam proses menemukan jawaban terhadap keinginan untuk memenuhi tujuan tersebut. Di antara tujuan tersebut adalah seperti yang dinyatakan oleh Francis Bacon yang dikutip oleh The Liang Gie dalam bukunya, dia mengatakan the real and legitimate goal of the science is teh endowment of human life with new inventions and riches. (tujuan sah dan senyatanya dari ilmu-ilmu adalah sumbangan terhadap hidup manusia dengan ciptaan-ciptaan baru dan kekayaan). Dengan tujuan-tujuan tersebut maka lahirlah ilmu pengetahuan yang berbeda-beda sebagai salah satu bukti dari reaksi kondisi mereka terhadap fenomena alam yang menjadi fakta saat itu. The Liang Gie, (2004 : 96)

Segala bentuk aktivitas ilmiah manusia itu menjadi tanda bahwa manusia sangat butuh untuk mengisi kehausan intelektualitasnya, sehingga setelah proses penciptaan metode-metode dalam pencarian ilmu pengetahuan maka lahirlah beberapa disiplin ilmu pengetahuan yang betul-betul diakui dan ilmiah, sehingga menjadi sandaran dalam proses menjalani hidup. 
Dengan demikian, proses keilmuan yang dilakukan oleh manusia senantiasa berkembangan dari yang sangat konvensional menjadi lebih formal dan ilmiah dengan menjadikan ilmu yang mereka hasilkan sebagai salah satu prosedur atau langkah dalam proses pendekatan yang mereka lakukan.

Di dalam makalah ini, penulis berusaha mengulas sekilas tentang ilmu pengetahuan sebagai prosedur manusia dalam proses keilmuan menusia. Penulis akan membatasi penulisan makalah ini pada pembahasan prosedur-prosedur ilmiah yang meliputi epistemologi, langkah-langkah ilmiah atau metode ilmiah yang harus ditempuh dalam proses pendekatan terhadap fenomena alam, sehingga melahirkan kesimpulan yang betul-betul diakui secara ilmiah.

\section{B. PEMBAHASAN}

\section{Pengertian Ilmu}

Sebelum penulis mengulas secara lugas tentang ilmu pengetahuan sebagai prosedur, terlebih dahulu penulis akan sedikit mengungkap tentang defenisi ilmu.

Kata "ilmu" merupakan diambil dari istilah yang sering dikenal dengan kata science, yang secara etimologis berasal dari kata latin scinre, artinya to know. tetapi kata scire juga berarti belajar (to learn). The Liang Gie, ( 1996 : 85 ) Ada juga yang mendefenisikan ilmu pengetahuan dengan pemahaman yang berbeda, yaitu seperti apa yang dinyatakan oleh Michael Ruse dalam tulisannya tentang Creation - Science is not science, yang dikutip oleh Martin Curd, bahwa science is a phenomenon that has developed through the ages- dragging itself apart from religion, philoshopy, superstition, and other bodies of human opinion and belief (Ilmu pengetahuan adalah sebuah fenomena yang berkembang dari masa ke masa dan menjadi bagian dari agama, filsafat, takhayul, dan bagian dari pemikiran dan keyakinan manusia). Martin Curd \& J. A. Cover, ( $1998: 39)$

Sedangkan J.J. Davies di dalam On the Scientific Method mengartikan ilmu sebagai suatu struktur yang dibangun di atas fakta-fakta. A.F. Chalmers , (1983:1) Michael Ruse mendefenisikan Science is a phenomenon that has developed through the ages-dragging itself apart from religion, 
philosophy, superstition, and other bodies of human openion and belief. Michael Ruse, , ( $1998: 39$ )

Kamudian dalam "Dictionary of Phylosophy" oleh Runes diartikan: Knowledge; relation know. Apprehended truth. Opposite of opinion. Certain knowledge is more than opinion, less than truth. Runes, Dagobert D., Dictionary of philosophy( $1983: 161$ ), ( ilmu pengetahuan, yang berhubungan dengan tahu. Kebenaran yang dimengerti. Lawan dari opini. Ilmu pengetahuan tertentu lebih daripada pendapat, tetapi ukurannya di bawah jika dibandingkan dengan kebenaran). Lebih lanjut di dalam "American Peoples Encyclopedia." Kata knowledge diartikan: knowledge, ideally a full and evident awarness of the truth with respect to anything; practically, an orderly awarness of whatever can definetly be accepted as real. ( t.th : 944 ) (Ilmu pengetahuan, suatu kesadaran penuh dan terbuktikan dari suatu kebenaran mengenai sesuatu; bersifat praktis, tersusun secara defenitif yang dapat diterima sebagai realita).

"Dictionary of Phylosophy" oleh Runes diartikan : Knowledge ; relation know. Apprehended truth. Opposite of opinion. Certain knowledge is more than opinion, less than truth. Runes, Dagobert D. ( 1983 : 161 ), ( ilmu pengetahuan, yang berhubungan dengan tahu. Kebenaran yang dimengerti. Lawan dari opini. Ilmu pengetahuan tertentu lebih daripada pendapat, tetapi ukurannya di bawah jika dibandingkan dengan kebenaran). Lebih lanjut di dalam "American Peoples Encyclopedia." Kata knowledge diartikan: knowledge, ideally a full and evident awarness of the truth with respect to anything; practically, an orderly awarness of whatever can definetly be accepted as real. ( t.th: 944 ) (Ilmu pengetahuan, suatu kesadaran penuh dan terbuktikan dari suatu kebenaran mengenai sesuatu; bersifat praktis, tersusun secara definitif yang dapat diterima sebagai realita).

Kemudian, Stewarr Richards mendefenisikan ilmu pengetahuan sebagai pengetahuan tentang realitas yang nyata yang dipastikan oleh pengamatan, pengujian kritis, dan pengklasifikasian sistematis di bawah prinsip-prinsip umum. Ilmu pengetahuan juga harus bersifat universal dan tidak terikat dengan ruang dan waktu, dan daapat dinyatakan dengan tegas. Stewart Richards, An Introduction to (1983: 28 )

Dari beberapa ragam defenisi yang dipaparkan diatas dapat dipahami bahwa ilmu pengetahuan itu lebih mendekati kepada proses, aktivitas, dan kesadaran manusia melalui instrumen akal sebagai konsekwensi dari respon manusia terhadap fakta-fakta fenomenologi yang terjadi di sekitar di mana ia berpijak. 


\section{Metode Dalam Memperoleh Pengetahuan}

Dalam buku Element of Philosophy Louis O. Kattsoff menunjukkan ada lima aliran metodis untuk mendapatkan ilmu pengetahuan, yaitu: Empirisme, Fenomenalisme, Intusionisme, dan Metode ilmiah.

\section{1) Empirisme}

Penganut aliran ini mengatakan bahwa ilmu pengetahuan dapat diperoleh dengan melalui pengalaman. Hal ini berangkat dari pertanyaan tentang bagaimanakah orang mengetahui es membeku ? dan rata-rata jawaban yang dikemukakan adalah "karena saya melihat yang demikian itu adanya", atau karena ilmuan mengetahui kenyataannya memang demikian. Louis O. Kattsoff, ( 2004 : 132 ) Sehingga Jhon Locke, bapak empiris mengatakan bahwa pada waktu manusia dilahirkan, akalnya merupakan sejenis buku catatan kosong (tabula rasa), dan di dalam buku catatan itulah dicatat pengalaman-pengalam indrawi. Dan seluruh pengetahuan itu diperoleh dengan jalan menggunakan serta membandingkan ide-ide yang diperoleh dari penginderaan dan refleksi sederhana tersebut.

Empirisme mempunyai beberapa bentuk, di antaranya adalah bentuk sensionalime yang sempit, mengatakan bahwa pengetahuan itu adalah merupakan rasa (sense), di samping rasa tidak ada pengetahuan. Aliran sensasionalisme adalah merupakan aliran empirisme radikal karena memberikan penekanan yang besar kepada inderawi, sebagaimana dilontarkan oleh David Hume sebagaimana yang dikutip oleh Imam Wahyudi bahwa pengetahuan manusia semata-mata disusun berdasarkan pengalaman indera sehingga disebut pengetahuan inderawi. Imam Wahyudi, 40

Pengalaman merupakan akibat suatu objek yang merangsang alat indrawi, yang secara demikian menimbulkan rangsangan saraf yang diteruskan ke otak. Di dalam otak, sumber rangsangan tadi dipahami sebagaimana adanya. Atau berdasarkan rangsangan tersebut dibentuklah tanggapan mengenai objek yang telah merangsang alat inderawi, begiitulah inderawi itu terbentuk.

2) Rasionalisme

Aliran ini berpendapat bahwa sumber pengetahuan itu terletak pada akal. Rasionalisme tidak menyangkal adanya pengalaman, akan tetapi pengalaman hanya dilihat sebagai perangsang bagi pikiran. 
Rasionalisme meyakini bahwa kebenaran dan kesesatan terletak dalam ide bukan di dalam barang/sesuatu. Sehingga rasionalisme mengatakan bahwa sumber pengetahuan itu terletak pada akal. Bukan rasionalisme mengingkari nilai pengalaman, tetapi ia dipandang tidak lebih dari hanya sekedar perangsang akal. Louis O. Kattsoff, 135

Descartes, sebagai bapak rasionalisme kontinental, berusaha menemukan suatu kebenaran yang tidak dapat diragukan dengan memakai metode deduktif dapat disimpulkan semua pengetahuan kita. Dengan memberikan penekanan pada metode itu, para penganut rasionalisme mengakui bahwa kebenaran-kebenaran yang dikandung oleh kesimpulan-kesimpulan yang diperolehnya sama banyaknya dengan kebenaran-kebenaran yang dikandung oleh premis-premis yang mengakibatkan kesimpulan-kesimpulan tersebut. Sehingga jika kesimpulan itu diinginkan menjadi pengetahuan, maka premispremisnya harus benar.

Sebagai suatu kegiatan berpikir maka penalaran mempunyai ciri tertentu, yaitu pola pikir logika. Logika dan matematika adalah hasil dari pada akal, bukan dari indra; walaupun begitu keduanya memberikan pengetahuan yang dapat diandalkan.

Penalaran itu sendiri terbagi dua macam :

a. Penalaran deduktif, yaitu evolusi mendasarkan pemikiran pada pengalaman yang luas nebuju kesimpulan yang sempit, dari yang general kepada pengertian baru yang sifatnya partikular, dari abstrak-teoritis menuju konkrit empiris.

b. Penalaran induktif adalah suatu proses pengetahuan, melaluinya menusia mengambi kesimpulan yang sifatnya umum berdasarkan hal yang sifatnya khusus, dari partikular menuju hal yang general. Imam Wahyudi, 45-46

\section{3) Fenomenalisme}

Fenomenalisme merupakan suatu pengetahuan yang mensintesakan antara apriori dengan aposteriori. Kant sebagai bapak perintis metode ini menyatakan bahwa sesuatu itu dapat merangsang inderawi, kemudian diterima oleh akal dalam bentuk pengalaman, dan dihubungkan sesuai dengan kategori-kategori pengalaman, dan disusun secara sistematis 
dengan jalan penalaran. Dengan demikian, setiap orang tidak dapat memiliki pengetahuan tentang sesuatu sesuai dengan keadaannya sendiri, melainkan hanya seperti sesuatu seperti yang nampak kepadanya, yang disebut dengan pengetahuan yang menggejalan (phenomenom).

Dalam hal ini Edmund Husserl (1839-1939) sebagaimana dikutip oleh Drs. Asmoro Ahmadi, menyatakan bahwa bahwa untuk mengetahui benda atau sesuatu harus menggunakan metode diskriptif fenomenologis yang didukung oleh diduktif yang bertujuan untuk melihat gejala-gejala yang secara intuitif. Maka dengan demikian, sesorang tidak mungkin dapat memahami kondisi sesuatu itu secara absolut (hakiki), akan tetapi hanya memahami kondisi sesuatu itu secara eksistensial-fenomenal. Asmoro Achmadi, (2001: 122 )

\section{4) Intuisionisme}

Dalam hal ini ada ungkapan komparasi tentang pengetahuan yaitu pengetahuan mengenai (knowing about) dan "pengetahuan tentang" (knowledge of) "pengetahuan mengenai". Pengetahuan ini dinamakan pengetahuan diskursif atau pengetahuan simbolis dan pengetahuan ini ada perantaranya. Pengetahuan tentang, disebut dengan pengetahuan langsung atau pengetahuan intuitif, dan pengetahuan tersebut diperoleh secara langsung. Louis O. Kattsoff, 140

Pengetahuan yang diperoleh dari intuisi tidak dapat dibuktikan seketika melalui kenyataan, karena pengetahuan ini muncul tanpa adanya pengalaman terlebih dahulu. Pemakaian metode intuitif secara tunggal dapat menghasilkan ilmu pengetahuan yang tidak masuk akal. Hal ini dapat dikendalikan dan dihindari apabila dicek dengan akal dan indera.

Epistemologi intuitif berpandangan bahwa dalam upaya memperoleh pengetahuan bukan bertumpu pada logika Aristotelian yang mengharuskan adanya jarak antara subjek dan objek, malainkan justru jalan utama untuk mengetahui adalah "menjadi". Dalam menjadi dapat menggapai pemahaman langsung tanpa perantara, sehingga memungkinkan tergapainya pengetahuan orisinal. Memang dalam keadaan "menjadi" kadangkala peran subjek kurang aktif, sebab keaktifan subjek kadangkala justru sering mengganggu pancaran kebenaran objek. 
Kelemahan intuisi adalah bahwa ia tidak merupakan metode aman jika dipakai sendirian. Ia dapat tersesat dengan mudah dan mendorong kepada pengakuan-pengakuan yang tidak masuk akal kecuali dicek dengan akal dan indera. Intuisi harus minta bantuan indera dan konsepkonsep akal jika berusaha untuk berhubungan dengan pihak lain dan menjelaskan dirinya dan mempertahankan diri dari interpretasi.

\section{5) Metode Ilmiah}

Metode ini mengikuti prosedur-prosedur tertentu yang sudah pasti yang sudah digunakan dalam usaha memberi jawaban atas pertanyaan-pertanyaan yang dihadapi oleh seorang ilmuan. Unsur pertama dalam metode ini, sejumlah pengamatan yang dipakai dasar untuk merumuskan masalah. Bila ada suatu masalah dan sudah diajukan satu penyelesaian yang dimungkinkan, maka penyelesaian yang diusulkan itu dinamakan "hipotesa".

Hipotesa adalah usulan penyelesaian yang berupa saran daan sebagai konsekwensinya harrus dipandang bersifat sementara dan diverifikasi. Di dalam proses menemukan hipotesa dikatakan bahwa akal keluar dari pengalaman, mencari satu bentuk, di dalamnya disusun fakta-fakta yang sudah diketahui dalam suatu kerangka tertentu dengan harapan fakta-fakta tersebut cocok dengan hipotesa yang disarankan tersebut. Maka metode penalaran yang bergerak dari suatu perangkat pengamatan yang khusus kearah suatu pernyataan mengenai semua pengamatan yang sama jenisnya dikenal dengan induksi.

Jika hipotesa telah diusulkan, maka perlu diverifikasi atau perlu bahan-bahan bukti. Sedangkan bahan bukti yang dapat memperkuat hipotesa berasal dari dua jurusan:

a. Bahan-bahan keterangan harus diketahui harus cocok dengan hipotesa tersebut.

b. Hipotesa itu harus meramalkan bahan-bahan keterangan yang dapat diamati, yang memang demikian keadaannya. Proses yang terjadi yang menunjukkan bahwa bahan-bahan keterangan yang diketahui itu cocok dengan hipotesa dapat dinamakan kalkulasi. Louis O. 144 
Jadi, kajian terhadapa hipotesa dimulai dengan pengamatan yang dilakukan secara hati-hati, sistematis, dan secara sengaja terhadap ramalan-ramalan yang disimpulkan dari hipotesa tertentu. Jika mungkin seorang ilmuwan harus mempersiapkan segala hal bagi pengamatanpengamatan yang dilakukannya . ia membuat alat-alat untuk mencoba menahan apa yang akan terjadia dan tatkala terjadinya, dan memakai pesawat-pesawat pengukur untuk mencatat apa yang terjadi. Dan ini dinamakan eksperimentasi. Ibid, 144-145

\section{6) Pengetahuan Ilmiah}

Pengetahuan ilmiah merupakan langkah pengembangan dari epistemologi. Popper yang dikutip oleh Alfon Taryadi, menyatakan bahwa studi terhadap pengetahuan ilmiah merupakan studi yang paling bermanfaat dan bagus untuk mempelajari pertumbuhan pengetahuan pada umumnya, sebab pengetahuan ilmiah adalah merupakan pertumbuhan dari pengetahuan sehari-hari yang tertulis secara garis besar. Selain itu, problem yang paling menarik dalam epistemologi adalah problem pertumbuhan pengetahuan, terutama pertumbuhan pengetahuan ilmiah, yang akan tak terjangkau oleh studi-studi pengetahuan biasa sehari-hari. Dengan demikian, Popper mengidentikkan pengetahuan ilmiah dengan epistemologi. Alfon Taryadi, (1991: 177)

Pengetahuan sehari-sehari itu merupakan pengatahuan yang hanya berdasarkan pada trial and error. Ia merupaka hasil dari uji coba yang hanya dicoba-coba sehingga pengatahuan sehari-hari itu tidak akan dapat dipahami, manakala riset dipandang secara ekslusif lewat revolusi-revolusi yang adakalanya dihasilkan oleh riset.

Dengan demikian, perkembangan pengetahuan ilmiah menimbulkan masalah-masalah yang meliputi penggolongan, pembagian, perincian, pembedaan, kedudukan, dan hubungan satu sama lain di atara bidangbidang pengetahuan ilmiah itu yang sering diosebut dengan ilmu pengetahuan baru.

Pemunculan pengetahuan baru itu terjadi karena beberapa faktor. Dalam hal ini The Liang Gie dengan mengutip tulisan Bert Hoselitz menyebut faktor itu kepada tiga saja :

a. Pengakuan dan kebaradaan problem baru yang dapat mempengaruhi terhadap perhatian para penyelidik atau peneliti. 
b. Pengumpulan data-data yang kemudian dielaboraasikan dengan hal-hal yang general untuk menemukan titik pokok persoalan tersebut.

c. Usaha institusi dalam mengakui munculnya disiplin baru tersebut. The Liang Gie, 152

Berkembang biaknya cabang-caabang ilmu khusus itu menimbulkan masalah pokok tentang penggolongan ilmu-ilmu tersebut dan pembagiannya. Klasifikasi ilmu pengetahuan merupakan pengaturan secara sistemik untuk menegaskan defenisi-defensi suatu cabang ilmu, menentukan batasan-batasannya, dan menjelaskan korelasinya dengan cabang-cabang yang lain.

Adapun pernyataan yang membuat pengetahuan itu menjadi pengetahuan ilmiah adalah :

a. Deskripsi

Yaitu memberikan pernyataan bersifat deskriptif dengan menjelaskan bentuk-bentuk, susunan, peranan, dan hal-hal terperinci lainnya dari segala fenomena.

b. Preskripsi

Pernyataan ini memberikan petunjuk-petunjuk atau ketentuanketentuan mengenai apa yang perlu berlangsung atau sebaiknya dilakukan dalam hubungannya dengan objek sederhana itu. Bentuk-bentuk ini banyak dijumpai dalam ilmu-ilmu sosial, dan ilmu-ilmu pendidikan yang meliputi tata cara mengajar dikelas.

c. Eskposisi pola

Bentuk ini merangkum banyak pernyataan-pernyataan yang memaparkan pola-pola dalam sekumpulan sifat, ciri, kecendrungan, atau proses lainnya dari fenomena yang sedang ditelaah. Misalnya dalam antropologi dapat dipaparkan pola-pola kebudayaan berbagai suku bangsa atau dalam sosiologi dibeberkan pola-pola perubahan masyarakat pedesaan menjadi masyarakat perkotaan.

d. Rekonstruksi Historis

Bentuk ini merupakan pernyataan-pernyataan yang berusaha menggambarkan atau menceritakan dengan penjelasan atau alasan yang dibutuhkan pertumbuhan sesuatu hal pada masa lampau yang jauh baik secara alamiah atau karena campur tangan manusia. 
Cabang-cabang ilmu khusus yang banyak mengandung bentuk pernyataan ini misalnya adalah historiografi, ilmu purbakala, dan paleontologi.

Pengetahuan ilmiah adalah merupakan pengetahuan yang diperoleh dengan menerapkan metode ilmiah. Metode keilmuan adalah merupakan bentuk kombinasi daari pola rasionalisme dan empirisme. Metode keilmuan muncul sebagai usaha untuk mengatasi kelemahan dari pola rasionalis maupun pola empiris, dan dimanfaatkan sumbangan positifnya.

Unsur-unsur metode ilmiah sebagai suatu penelitian ilmiah antara lain berupa satu prosedur sebagai berikut ;

1. Perumusan masalah atas objek yang ingin diketahui.

2. Mengajukan hipotesi atau dugaan sementara atas permasalahan yang ada.

3. Menguji hipotesis dengan fakta-fakta empiris.

4. Mengambil kesimpulan atas pengujian yang telah dilakukan, apakah hipotesis didukung oleh fakta ataukah dibantah oleh fakta. Imam Wahyudi, 36

\section{7) Metode Ilmiah}

Metode ilmiah merupakan satu prosedur yang mencakup berbagai tindakan pikiran, pola kerja, cara teknis, tata langkah untuk mengetahui pengetahuan baru atau mengembangkan pengetahuan yang telah ada.

Metode secara etimologis berasal dari bahasa Yunani, Meta yang berarti sesudah, dan Hodos yang berarti jalan. Jadi metode berarti langkah-langkah yang diambil, menurut urutan tertentu, untuk mencapai pengetahuan yang benar, yaitu suatu tata cara, tekhnik atau jalan yang telah dirancang dan dipakai dalam proses memperoleh pengetahuan jenis apapun, baik pengetahuan humanistik dan hisstoris, atau pengetahuan filsafat dan ilmiah. Tim Dosen Filsafat Ilmu Fakultas Filsafat UGM,129

Pada dasarnya pola umum dalam metode ilmiah ini dapat dipakai dengan melihat sejarah perkembangan ilmu itu sendiri yang telah berlangsung dari abad ke abad. Sekaligus dengan melihat perkembangan 
ilmu pengetahuan tersebut, dapat dipahami bahwa tersebarnya ilmu pengetahuan menjadi banyak cabang ilmu-ilmu khusus antara lain berhubungan dengan metode ilmiah yang digunakan. Berbedanya ilmu-ilmu yang ada menunjukkan perbedaan metode yang digunakan dalam proses pendekatannya, menyelidiki, merumuskan, dan mengerti realitas.

Corak-corak metodologis yang digunakan dan dikembangkan menyebabkan ilmu pengetahuan itu bersifat pisitivistik (bebas dari pikiran etik), deterministik (berdasarkan pada hukum-hukum kausalitas), evolusionistik (melihat sejarah sebagai dasar dalam menentukan objek yang diteliti), sehingga segala sesuatu harus dijelaskan dengan melalui metode kunatitatif dan eksperimental melalui observasi.

Periode ini juga ditandai dengan semakin terkotak-kotaknya ilmu pengetahuan ke dalam ilmu-ilmu khusus dalam bidang spesialisasi. Sehingga terjadilah differensiasi ilmu pengetahuan, sebagaimana yang dijelaskan oleh Lewis buku Filsafat Ilmu yang dikutip oleh Tim dosen UGM Yogyakarta bahwa " ilmu khusus telah muncul dengan cara yang ditunjukkan. Ilmu-ilmu tersebut berkembang dalam matriks umum dari pemikiran reflektif dan menjadi diakui berbeda. Bila mana suatu kedewasaan tercapai pada umumnya, ilmu fisikalah yang pertamatama mengalami perkembangan ini, ilmu-ilmu kemanusiaan, budaya, psikologi, antropologi, sosiologi, ekonomi, dan pemerintahan adalah yang terakhir menjadi terpisah dari filsafat.

Sifat ilmiahnya suatu pengetahuan terletak pada kelangsungan proses yang runtut dari segenap tahapan prosedur ilmiah tersebut, meskipun pada perakteknya tahap-tahap kerja tersebut sering kali dilakukan secara bersamaan.

Tahap pertama adalah observasi, maka yang dimaksudkan adalah bahwa tahap ini berlangsung hanya sekedar melakukan pengamatan biasa. Kenyataan empirik yang terjadi, maka objeknya diteliti, dikumpulkan, diidentifikasi, didaftar, dan diklasifikasikan secara ilmiah. Observasi bertugas mencari benang merah dari bahan-bahan tersebut dan disororti dalam suatu kerangka ilmiah.

Tahap kedua adalah induksi. Dalam hal ini, pernyataan suatu observasi dinyatakan dalam bentuk pernyataan yang umum. Induksi dipermudah dengan menggunakan alat-alat bantu matematik dalam merumuskan serta mengumpulkan data-data empirik. Pengukuran secara 
kuantitatif terhadap besaran-besaran tertentu yang saling berhubungan, maka hubungan tersebut dapat digambarkan dalam simbol matematika. Apabila suatu kejadian dapat terjadi secara berulang-ulang, maka pernyataan umum tersebut memperoleh kedudukan sebagai hukum.

Tahap ketiga adalah dilaksanakannya deduksi-deduksi logisi, yaitu data-data empirik diolah lebih lanjut dalam suatu sistem yang runtut. Penyusunan sistem seperti ini juga tergantung dipergunakannya pengertian-pengertian operasional tertentu, yaitu bahasa buatan dalam rangka pembentukan teori ilmiah. Tim Dosen Filsafat Ilmu Fakultas Filsafat UGM, 132

Berdasarkan sistem seperti ini dapatlah dijabarkan pernyataanpernyataan yang khsus tertentu.

Tahap keempat adalah observasi eksperimental, yaitu pernyataan yang telah dijabarkan secara deduktif. Diuji dengan melakukan verifikasi atau klarifikasi secara empirik. Verifiksi atau klarifikasi secara empirik dimaksudkan untuk mengukuhkan pernyataan-pernyataan rasional hasil deduksi sebagai teori.

Verifikasi merupakan tahapan untuk mengukuhkan atau menggugurkan pernyataan-pernyataan rasional hasil dari deduksideduksi logis.

Jadi kesimpulannya metode ilmiah merupakan prosedur yang mencakup tindakan pikiran, pola kerja, cara teknis, tata langkah untuk memperoleh pengetahuan, atau mengembangkan pengetahuan. Pola umum tata langkah dalam metode ilmiah yang berkembang menyebabkan ilmu pengetahuan bersifat positivistik, deterministik, evolusionistik, sehingga analisisnya selalu dibantu dengan pendekatan kuantitatif dan eskperimen melalui observasi.

Ilmu-ilmu kealaman pada umumnya menggunakan metode siklusempirik dan objektivitasnya di uji secara empiris-eksperimental. Ilmuilmu sosial dan humanistik pada umumnya menggunakan metode linear dan analisisnya dimaksudkan untuk menemukan arti, nilai dari pengetahuan, dan tujuan akhir dari pada ilmu pengetahuan tersebut. Sehingga maksud dan tujuan itu secara tidak langsung dapat digapai dan diketahui dengan jelas. Tim Dosen Filsafat Ilmu Fakultas Filsafat UGM, 134 
Dari beberapa metode yang dilakukan dalam proses aktivitas ilmiah yang dilakukan, maka akan dihasilkan suatu kesimpulan yang benar secara ilmiah yang dikenal dengan kebenaran ilmiah.

Kebenaran ilmiah merupakan suatu pengetahuan yang jelas dan pasti kebenarannya menurut norma-norma keilmuan. Adapun kebenara yang pasti adalah mengenai suatu objek materi, yang diperoleh menurut objek forma, metode, dan sistem tertentu.

Kebenaran ilmiah cendrung bersifat objektif, tidak subjektif. Artinya terkandung di dalamnya sejumlah pengetahuan menurut sudut pandang yang berbeda-beda, tetapi saling bersesuaian. Dengan demikian, dapat dipastikan ia tahan terhadap verifikasi baik yang empirik maupun yang rasional. Hal ini wajar, karena sudut pandang. Metode dan sistem yang dipakai juga bersumber dari pengalaman maupun akal pikiran.

Sumber kebenaran ilmiah dapat dilihat atau diukur dari dua aspek, yaitu : Raionalisme dan Empirisme. D. W. Hamlyn, ( 1990 : 134-135 )

\section{KESIMPULAN}

Dari apa yang telah dipaparkan oleh penulis dalam bab pembahasan tersebut dapat disimpulkan bahwa :

Terdapat beberapa metode dalam memperoleh ilmu pengetahuan, di antaranya adalah dengan metode rasionaslime, empirisme, fenomenalime, intusionalisme, dan metode ilmiah.

Pengetahuan ilmiah dapat dinyatakan dengan melalui beberapa tahapan yaitu diskripsi, priskripsi, rekonstruksi pola, dan rekonstruksi historis.

Unsur-Unsur dalam metode ilmiah sebagai suatu penelitian ilmiah antara lain dengan melalui beberapa prosedur, di antaranya aadalah perumusan masalah, mengajukan hipotesis, menguji hipotesis dengan fakta empiris, dan mengambil kesimpulan. 


\section{DAFTAR PUSTAKA}

American Peoples Encyclopedia, New York: Grolier Ins., t.th

Stewart Richards, An Introduction to: Philosophy of sociology of science, Oxford: Tj Press, 1983

Michael Ruse, Creation- Science is not Science," dalam Martin Curd and and J.A. Cover (eds)., Philosophy of Science: The Central Issus, New York and London: W.W Northon Company, 1998

Martin Curd \& J. A. Cover, Philoshopy of Science (the central issue), Newyork; w. w. Norton \& Company, 1998

W. Hamlyn, The Penguin History of Western Philosophy, England: The Penguin Group, 1990

Dagobert D. Dictionary of philosophy, (New Jersy: Little field Adam \& CO, 1983

Alfon Taryadi, Epitemologi Pemecahan Masalah menurut Karl. R. Popper, Jakarta: PT Gramedia Utama, 1991

George J. Mouly, “ Perkembangan Ilmu, “ dalam Jujun S. Suriasumantri, Ilmu dalam Perspektif Sebuah Kumpulan Karangan Tentang Hakikat Ilmu Jakarta : Yayasan Obor Indonesia, 1999

Asmoro Achmadi, flilsafat Umum, Jakarta: PT. Grafindo Persada, 2001

Tim Dosen Filsafat Ilmu Fakultas Filsafat UGM, Filsafat ILmu, Yogyakarta; Liberti 2003 ., Filsafat ILmu sebagai Dasar Pengembangan Ilmu Pengetahuan, Yogyakarta; Liberti 1996

The Liang Gie, Pengantar Filsafat Ilmu, Yogyakarta, Liberty Cet. VI, 2004

Jujun S. Suria Sumantri, Filsafat Ilmu sebuah Pengantar Populer, Jakarta; Pustaka Sinar Harapan,cet.14, 2001

Imam Wahyudi, Pengantar Epistemologi, Yogyakarta, Badan Penerbitan Filsafat UGM Bekerja sama dengan Lima \& Faisal Foundation

R. A. Rivai (Terj), Filosofie Filosofen Filosoferen, Jakarta, Erlangga,tth Suparman Syukur, Epistemologi Islam Skolastik, Yogyakarta, Pustaka Pelajar bekerja sama dengan IAIN Walisongo Semarang, 2007 
Lailatul Maskhuroh - Ilmu Sebagai Prosedur...

Donny Gahral Adian, Menyoal Objektivisme Ilmu Pengetahuan, Yogyakarta: Teraju, 2002

A.F. Chalmers ,Apa yang dinamakan Ilmu? Terj. Redaksi Hasta Mitra Jakarta:Hasta Mitra, 1983

Asmoro Ahmadi, Filsafat Umum, Jakarta, Rajawali Press, cet. 4, 2001

Sidigazalba, Sistematikan Filsafat, Jakarta; Bulan Bintang,cet.6, 1992

Jerpme R. Ravertz, Filsafat Ilmu Sejarah \& Ruang Lingkup Bahasan, Pustaka Pelajar, tth

K. Bertens, Ringkasan Sejarah Filsafat, Yogyakarta, Kanisius, Cet. 15, 1998

I. R. Poedjawijatna, Pembimbing Ke Arah Alam Filsafat, Jakarta, Rineka Cipta, cet. 12, 2005

Suparlan Suhartono, Filsafat Ilmu Pengetahuan Persoalan Eksistensi dan Hakikat Ilmu Pengetahuan, Jogjakarta, Ar-Ruzz Media, 2008

Cornelius Benjamin, Philoshopy of Science, History of Philoshopical Syistem, Amerika: Philoshopical Library, 1965

Alex Rosenberg, Philoshopy of Science, New York: UK Routledge, 2005

Meriam, Webster's New Collegiate Dictionary, New York: The World Pulishing Coy, 1979

FX. Mudji Sutrisno \& F. Budi Hardiman (Editor), Para Filsuf Penentu Gerak Jaman, Yogyakarta;Kanisius 1992 